\title{
Key factors in developing effective, successful and sustainable business incubators
}

\author{
John Regan, Ec.D. (F)
}

\begin{abstract}
Business incubators are proven to be effective for the growth and survival of small businesses. Given their reputation, this paper asks why they are not established in every community. Through the lens of Elgin Community Futures Development Corporation, the author examines the benefits of establishing a business incubator in St. Thomas, Elgin County, Ontario as a way to revitalize their economy after a severe economic downturn. A compilation of interviews with incubator managers, administrators and other experts in Elgin County builds the case for establishing a formal business incubator to permanently stimulate their economy.
\end{abstract}

Keywords: Business incubator, small business, job creation, Elgin Community Futures Development Corporation.

\section{Introduction}

"Small businesses are the engine of our economy." This well-worn phrase conjures up images of thousands upon thousands of moms and pops in their family owned businesses, toiling endlessly day and night, pursuing the thankless task of keeping the nation's economy humming along. Of course small businesses come in a variety of shapes, sizes and compositions, and their daily experiences are not as uni-dimensional as the preceding sentence would seem to indicate. The fact remains however, that the economies of our nation, our province, and every community depend on the continued growth and survival of small businesses. How dependent are we? Let's look at some of the facts.

Industry Canada defines a small business as a firm with fewer than 100 employees. Such firms account for $98 \%$ of all business in Canada and employ $48 \%$ of the total labour force in the private sector. Each and every year, nearly 140,000 small businesses are created in Canada. Sadly, the statistics also indicate that $30 \%$, or 42,000 of those new small businesses will not survive their first year, and an additional $20 \%$ or 28,000 will fail by year three. This begs the question: if small businesses are so important to us, what are we doing to reduce the incidence of failure within the small business sector?

The short answer is that, in North America, we've been nurturing some of our most promising new small businesses in "business incubators" for the better part of the last 50 years. There is very little debate about the effectiveness of business incubators. Studies have confirmed that the 
survival rate of "tenant companies" approaches nearly $90 \%$ in some instances. This inevitably makes one wonder why there are so few incubators nationwide (83 across Canada in 2005). Shouldn't every community have its own business incubator - if for no other reason than insurance against the inevitability of the death of small businesses?

Elgin Community Futures Development Corporation (Elgin CFDC) is in the process of considering the creation of an incubator at its location in St. Thomas, Ontario. Due to the severe economic downturn - specifically the negative impact of contraction in the auto industry - Elgin County, and in particular, the city of St. Thomas have garnered much attention in the regional and national media. In more prosperous times, St. Thomas was more likely to be referred to as the "Railway City," or, perhaps more morbidly, as the place where the famous elephant, Jumbo, met his demise. Nowadays, however, it seems that St. Thomas is on its way to earning the loathsome title "Ground Zero of the Canadian economic downturn." Elgin CFDC is determined to see that this title is never bestowed upon this city and the surrounding region.

This paper will examine:

- The profile of a community in need (i.e. the current business and economic climate in St. Thomas and Elgin).

- The roles of Elgin CFDC, and more specifically, its role in providing incubator-type services.

- The business incubator concept.

- The case for the establishment of a formal business incubator in conjunction with the existing suite of services offered by Elgin CFDC.

\section{Profile of a community in need}

\section{Current economic situation}

Table 1: Population

\begin{tabular}{|l|l|}
\hline City of St. Thomas - March, 2008 (estimated) & 38,536 \\
\hline $\begin{array}{l}\text { County of Elgin (includes the City of St. Thomas) - } \\
\text { March, 2008 } \\
\text { (estimated) }\end{array}$ & 87,655 \\
\hline Elgin Change in \% from 2006 - 2008 & 2.7 \\
\hline
\end{tabular}

Source: Statistics Canada, County of Elgin Profile, 2008. 
The London Census Metropolitan Area (CMA), which includes St. Thomas, saw a jump of 47\% in Employment Insurance (EI) recipients from February 2008 to February 2009. Given our knowledge of the local situation, it is safe to say that this figure is representative (and perhaps under-representative) of St. Thomas.

Net employment in the economic region of London fell by $4.2 \%$, or 13,800 jobs, from March 2008 to March 2009. Full-time employment decreased by 21,800 while part-time employment increased by 7,900. Consequently, the unemployment rate increased from 6.5\% in March 2008 to 9.7\% in March 2009, the highest rate since August 1996. Over the same period, the provincial rate increased from $6.5 \%$ to $8.9 \%$. As of May 2009 the unemployment rate rose to $10.7 \%$ (Service Canada, 2009)

\section{St. Thomas \& Elgin County}

In St. Thomas and Elgin County, the unemployment rates continue to significantly exceed the provincial and regional numbers. In St. Thomas, the rate soared to $14.8 \%$, making St. Thomas and area one of the regions with the highest unemployment in Ontario.

Table 2: Unemployment rate

\begin{tabular}{|l|l|}
\hline St. Thomas & $12.0 \%$ to $14.8 \%$ \\
\hline $\begin{array}{l}\text { Elgin County (with St. } \\
\text { Thomas) }\end{array}$ & $9.0 \%$ to $10.8 \%$ \\
\hline
\end{tabular}

Source: Employment Services Elgin, 2009; Elgin Local Training Board, 2009.

St. Thomas (population 36,000) and surrounding Elgin County (population 49,000) have been drastically affected by the decline of its major employment sector, manufacturing, particularly the transportation equipment manufacturing sector. To date the known job losses in that sector total 5,551. The major losses have come from the Ford Assembly plant (1,387 laid off- 1 shift shut down entirely); the Sterling Truck Plant (closed - 2,200 jobs lost); two Magna Plants, Formet (700 laid off) and Presstran (200 laid off); Therm-o-Disc (closed - 337 jobs lost); Timken (140 laid off); Lear (153 laid off); Walker Transport (56 laid off); Alcoa (closed - 152 jobs lost); Emerson (closed - 132 jobs lost); Schulman (closed - 128 jobs lost). This does not include the many job losses now occurring as a result of the major plant closures and layoffs, and many fear that the downsizing is not finished.

The other major employment sectors are farming (which is declining), health, education, and hospitality. Since farming represents the second largest sector in the area, it is worthwhile examining some of the economic realities associated with the industry. 
Elgin currently has 2,215 farm operators, representing $2.6 \%$ of the County's population. This is substantially higher than the $0.6 \%$ figure for the Province of Ontario. The fact that there are over four times more farm operators per capita in Elgin County than the provincial average, illustrates the very important impact of the agricultural sector on the County's economy. Consider these additional facts:

- 7,753 jobs, or $19.7 \%$ of County's total is tied to agriculture in Elgin;

- $\quad \$ 558$ million in sales from farms and businesses buying from and selling to farms; and

- over \$216 million farm expenditures were spent locally (Kenny, 2009).

The tobacco crop has been in steady decline since the government first announced its exit programs 15 years ago. To date, there have been three programs. The final Tobacco Transition Program (TTP) in 2009 saw 1,050 quota holders (individuals and business entities holding quotas) participate in the TTP which succeeded in retiring $99.8 \%$ of the entire quota. Tobacco has been the highest ROI crop in this region and is difficult to replace with a like crop. Over the years, a number of crop replacement initiatives have met with limited success for a variety of reasons, such as overproduction, unsuitable agronomy, duplication of crops driving down prices and/or lack of processing plants or crop marketing agencies.

In addition to the farmers losing a high ROI crop, the demise of tobacco has resulted in a decline in employment in the many farms, warehouses, processing plants and auction sites in the community. In 2004, according to Agriculture Canada, the total impact on local employment was a loss of close to 10,000 jobs and the evaporation of nearly $\$ 500$ million in income. These figures were surpassed in 2009.

St. Thomas and Elgin County have suffered serious economic setbacks. A small city has had its manufacturing base shattered and thousands of jobs have disappeared permanently. A rural county is experiencing the loss of a major and lucrative crop (tobacco) and its farmers are struggling. The impact on this small city and rural county has been nothing short of devastating.

\section{The Role of Elgin CFDC}

\section{Support for Business and Economic Development}

The Elgin Community Futures Development Corporation (CFDC), also known as the Elgin Business Resource Centre (Elgin BRC) is experiencing record inquires and has exceeded its support capacity by nearly $50 \%$. With increased traffic, comes increased participation in the self

employment benefits program (SEB), and increased applications for loans. Elgin CFDC's efforts are resulting in record numbers of people becoming self employed. This reality is part of the rationale for the current discussion about the creation of an incubation centre for Elgin County. 
While a number of the new businesses have the potential of creating a significant number of jobs, there are also many businesses being created that will likely result in the creation of only one job. The range of new businesses is quite diverse, from dog grooming to light manufacturing/ fabricating to heavy industry. It is important to recognize that, while all types of businesses need support from time to time, especially in their early stages, not all would benefit from being a resident within an incubator. However, all might perhaps benefit from virtual access to the services of an incubator.

Figure 1: Elgin CFDC total loans advanced

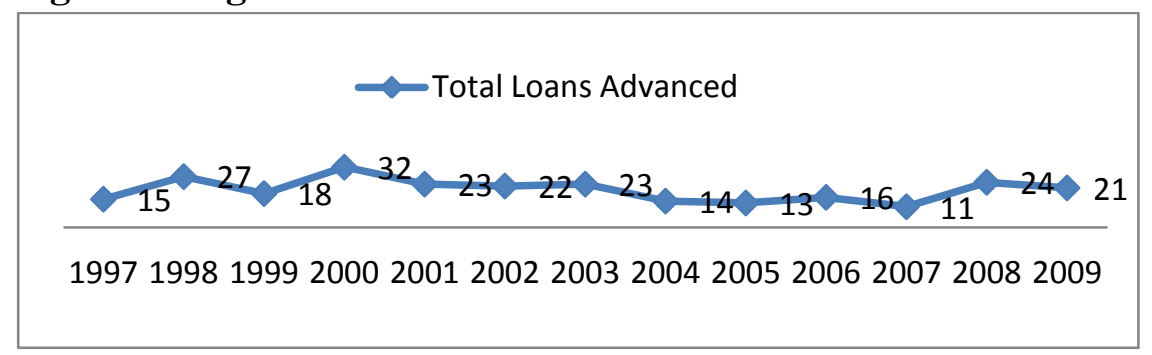

Source: Elgin Community Futures Corporation, 2009.

*2009 - as of September 2009 CFDC had 21 new loans out at \$1,124,465 with a forecast of 30 loans at an estimated $1.9 \mathrm{~m}$. by the end of 2009. The number of loans are on the rise and the amount being requested is significantly higher.

In 2008, Elgin CFDC extended $\$ 785,484$ in loans to 24 businesses. This represented a $118 \%$ increase in the number of loans approved over the previous year. This money also served to leverage further loans/investments of $\$ 1,445,137$, created 39 full-time and four part-time jobs, and assured the maintenance of 29 full-time and 11 part-time jobs. Elgin CFDC's portfolio of outstanding loans totaled \$1,670,921 across 44 businesses, as of December 2008.

The following outlines the impact that Canada's CFDCs and Community Business Development Corporations had from April 1, 2007 to March 31, 2008:

- 1,081 staff and 2,232 volunteers served a population of 9.1 million in 202 communities;

- 4,455 loans were granted at a total value of \$175.2 million; and

- 12,277 jobs were affected across rural and Northern Canada. 
Table 3: 2008 Financial ad employment impact of CFDCs

\begin{tabular}{|l|l|l|l|l|l|l|}
\hline Province & $\begin{array}{l}\text { \# of } \\
\text { CFDC/ } \\
\text { CBDCs }\end{array}$ & Staff & Volunteers & $\begin{array}{l}\text { \# of } \\
\text { Loans }\end{array}$ & $\begin{array}{l}\text { Value of } \\
\text { Loans } \mathbf{( \$ M )}\end{array}$ & Total Jobs \\
\hline NB & 10 & 92 & 128 & 588 & 25.2 & 2,036 \\
\hline NS & 13 & 73 & 139 & 599 & 18.7 & 1,088 \\
\hline NFL & 15 & 75 & 120 & 353 & 12.9 & 607 \\
\hline PEI & 3 & 10 & 19 & 94 & 2.4 & 22 \\
\hline ON & 61 & 264 & 781 & 1,130 & 55.9 & 6,435 \\
\hline $\begin{array}{l}\text { QUE }- \\
\text { estimated }\end{array}$ & 67 & 400 & 1,350 & 1,100 & 35.0 & 6,100 \\
\hline NU & 3 & 9 & 13 & 31 & 2.4 & 114 \\
\hline NWT & 5 & 10 & 31 & 106 & 5.0 & 377 \\
\hline BC & 34 & 311 & 344 & 638 & 31.0 & 2,082 \\
\hline SASK & 13 & 62 & 152 & 123 & 6.3 & 725 \\
\hline MAN & 16 & 85 & 246 & 168 & 8.1 & 763 \\
\hline ALBTA & 27 & 151 & $\mathbf{2 8 6}$ & 472 & 28.7 & 1,371 \\
\hline TOTAL & $\mathbf{2 6 9}$ & $\mathbf{1 , 5 4 2}$ & $\mathbf{3 , 6 0 9}$ & $\mathbf{5 , 4 0 2}$ & $\mathbf{\$ 2 3 1 . 5 6 1} \mathbf{M}$ & $\mathbf{2 1 , 9 2 0}$ \\
\hline Sourc: Ont & & & & & & \\
\hline
\end{tabular}

Source: Ontario Association of Community Futures Development Corporations (OACFDC), 2008.

The role of a CFDC is to support new and existing businesses through counseling and loan services. This includes providing:

- loans up to $\$ 250,000$;

- business plan development and assistance;

- SEB program;

- connecting businesses to resources; and

- community economic development services.

Elgin BRC provides support for existing and new small businesses through a variety of services and programs designed to help grow or get started in business. The CFDC also provides businesses with access to business and economic information.

Elgin BRC is a developmental lender providing qualified entrepreneurs with business loans of up to $\$ 250,000$ for start-up, expansion or preservation of an existing business within the region. The emphasis is on economic diversification and job maintenance or creation. A lending committee comprised of community volunteers provides added expertise to the loan review process. The committee members typically have successful business management or entrepreneurial 
experience, and are sufficiently familiar with local conditions and needs to make informed and effective lending decisions.

In addition to loans, CFDCs provide support in delivering community services. An example of this is the SEB program. The SEB program allows participants to continue to receive their employment insurance benefits while they are getting their businesses up and running. Following their acceptance into the program, qualifying individuals receive income support and business counseling (group training sessions, as well as one-on-one business counseling). The SEB program has been a catalyst for entrepreneurship and small business development in Elgin County. The chances of starting a successful, long-term business are much higher for individuals who receive the assistance of the SEB program. All SEB participants receive income support from employment insurance while involved in the program. This income support is of great assistance to entrepreneurs in the first year of business when revenues can be quite unpredictable.

Generally, those eligible for employment insurance do qualify for the SEB program. Once an applicant meets the criteria for eligibility, they are required to attend a series of concept workshops, followed by a series of business planning workshops. Their business plan is then assessed by a business counsellor and, if accepted, they enter into a contract with the Ministry of Training Colleges and Universities (MTCU).

\section{Figure 2: Elgin business created}

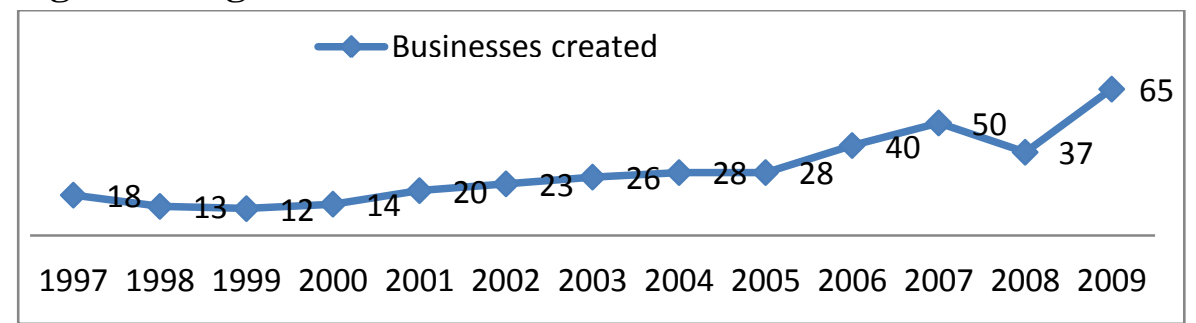

Source: Elgin Community Futures Corporation, 2009.

Elgin CFDC statistics indicate that $71 \%$ of the businesses that started during the period from 1998 to 2005 and received the benefit of our services are still operating. This contradicts the well documented historical fact that $2 / 3$ of new businesses fail within the first five years of existence and serves to illustrate that access to professional business counseling can have a significant impact on business sustainability.

Elgin CFDC believes that, despite its own success, there is a missing link between early intervention/access to counseling and long-term entrepreneurial success and sustainability. Elgin CFDC and its counterparts across Canada play a vital role in support of business incubation in Canada. As noted in the discussion above, a number of CFDCs are also operators of business 
incubators. Indeed, given their mandate and the scope of services they offer to new businesses, one could argue that all CFDCs function, in the very least, as informal virtual incubators.

\section{Review of business incubator}

\section{Definition and purpose}

Business incubators have existed in North America since the late 1950s. Joseph Mancuso is credited with creating the first formal business incubator in 1959 when he opened the Batavia Industrial Centre in a New York warehouse (Stone, 2008). In 2005, North American incubation programs provided assistance to more than 27,000 companies, employing over 100,000 people, and earned estimated annual revenues of over $\$ 17$ billion (Knopp, 2007).

The commonly accepted purpose of business incubators is to support and accelerate the development of new businesses through the provision of a controlled and structured environment, which provides ready access to necessary resources such as secretarial and administrative support, office and meeting facilities, and business expertise - in order to leverage entrepreneurial talent, encourage increased entrepreneurial activity and increase the success rate of new businesses. Incubators vary in the way they deliver their services; in their organizational structure and in the types of clients they serve. Completion of a program offered through an incubator program increases the success and sustainability of a start-up company. Experience shows that $87 \%$ of business incubator graduates will be sustainable businesses (NBIA, 2007).

Incubators are fundamentally different from the typical technology and research parks. Incubators focus primarily on new start-up or early stage developments, whereas research and technology parks will typically be larger scale developments that provide space to a wide scope of sectors, including government, universities and colleges, and small and medium-sized enterprises (SMEs). Most research and technology parks do not provide business assistance or services. However, there are examples of some that house an incubator program.

Starting a business or having an idea to start one does not grant the entrepreneur the privilege of automatic acceptance into an incubator program. A business incubator does not accept all. Generally speaking, entrepreneurs must apply and must meet criteria as set out by the incubator's policies and procedures. Though the criteria may change from incubator to incubator, a common practice is to accept as tenants only those businesses with viable concepts and business plans. This highlights an inherent difficulty in assessing the true effectiveness of a given incubator - it is populated by a process of cherry picking the "most likely to succeed" businesses, therefore affecting the success/failure rate. 
Although affordable square footage may appear to be the primary benefit, the essence of a successful business incubation program exists in the services it offers and the culture of comradery that it fosters among member companies.

A 2006 survey by the National Business Incubation Association reported that more than 50\% of incubators provided services to virtual and affiliate type clients (NBA, 2006). These companies do not have physical space within the facility, and are home-based businesses or early stage startups that have already acquired their own space. The virtual client receives services (counseling) electronically through webinars and video conferencing.

The duration of an incubation program seems to vary considerably and is affected by a number of factors. This includes, but is not limited to the level of experience and expertise of the entrepreneur and the type of business. For example, companies or organizations that have longer development and sales cycles such as those that are science-based and research and development intensive, require a longer tenancy than manufacturing or service companies. Generally, service and manufacturing companies are able to bring their product to the consumer sooner, and therefore can experience a fair degree of market-related growth within the first few years of operations. On average, incubator clients spend 33 months in an incubation program (NBA, 2006). Incubation programs will implement graduation requirements through benchmarks that include, or may include, revenue targets, space requirements due to growth, or an increase in staffing levels. It would be rare and perhaps impractical to base the program solely on time however, this is the criteria in some cases.

There are many different types of incubators including:

- Technology

- Computer software

- Internet

- Telecommunications

- Computer hardware

- Wireless technology

- Energy

- Environmental/ Green Technology

- Arts

- Media

- Retail

- Electronics

- Medical instrumentation

- Construction

- Forestry products 
- Services

According to research by the National Business Incubator Association, more than half of all programs could be considered "mixed-use" projects, that is, they have clients from a variety of sectors. Technology incubators make up 39\% of the incubation program (NBIA, 2001).

\section{Funding and structure}

Many regional or national governments, in keeping with their economic development strategies will allocate funds towards business incubator programs. In the United States, the majority of incubators are funded independently through community-based and resourced projects. While the United States Economic Development Administration is a source of startup funding for new business incubation ventures, incubators must typically fund their operations through earned revenues and other available funding after the startup phase. An average incubator in the United States receives $59 \%$ of its revenue from rent and other client fees, $18 \%$ from service contracts or grants, and $15 \%$ from operating subsidies.

It is interesting to note that, in the late 1990s, a large number of incubators were started by investors, ostensibly as a means to earn a quick profit. The National Business Incubation Association, at the time, estimated that almost $30 \%$ of all the incubators were registered as forprofit enterprises. After the dotcom bubble burst, many of these for profit incubators failed. Only $16 \%$ of the respondents to the 2002 NBIA survey indicated they were operating on a for-profit basis; by 2006 only 6\% were for-profit (NBIA, 2001).

\section{Location and growth}

According to the National Business Incubation Association, there are currently approximately 5,000 incubators worldwide. In 2006, there were over 1400 incubators in North America - a significant increase from the 12 that existed in 1980. In the United Kingdom, the number of incubators has grown from twelve in 1997 to over 270 in 2005. A European Commission study in 2002 suggested that in excess of 900 incubators were in operation in Western Europe at the time (CSES, 2002). Incubators are not only found in industrialized countries, but in developing nations as well. Support for these initiatives in developing nations is made available through UNIDO and the World Bank (UNIDO, n.d). 
Services

Figure 3 illustrates the services most commonly utilized by business incubator clients.

As noted earlier, numerous studies indicate that two out of three new businesses will fail prior to the fifth year of operation. Studies and common sense also show that the presence of professional business counseling and access to funding are required to grow businesses (Statistics Canada, 2005). There is little debate that the primary objective of an incubator is to help build, develop and grow companies, and in so doing, create as many jobs as possible.

\section{Figure 3: Most utilized services offered to clients}

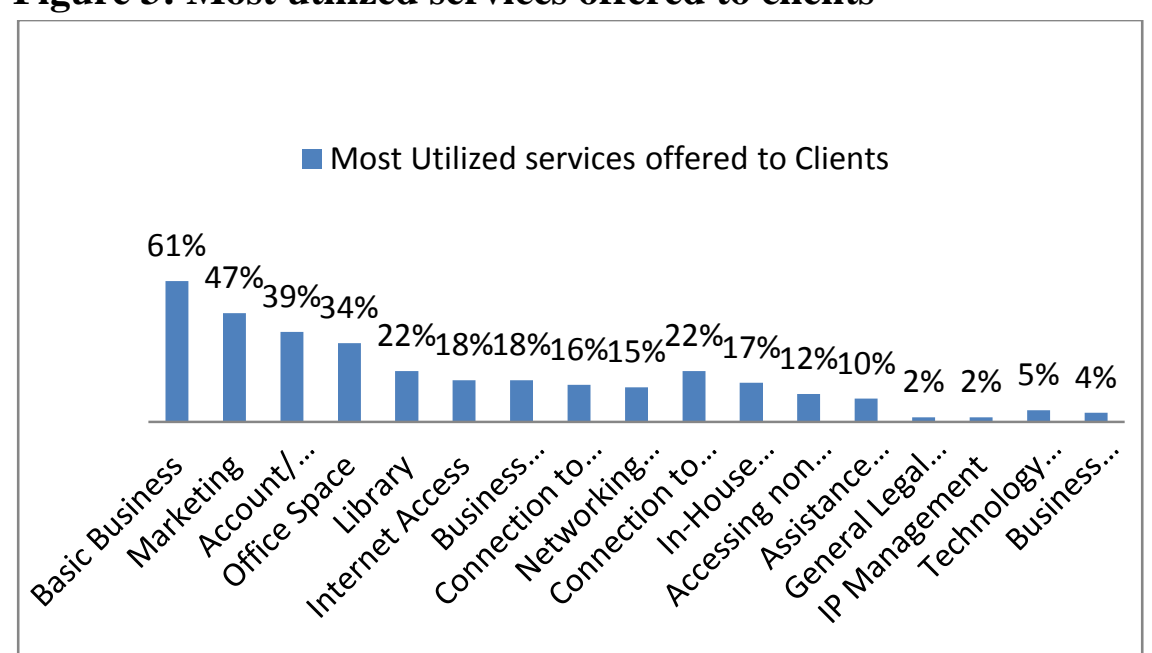

Source: Stats Canada, Characteristics of Business Incubation in Canada, 2005.

\section{The Canadian experience}

This section examines the operation of business incubators in Canada. Much of the discussion centres around data from a working paper titled, "Characteristics of Business Incubation in Canada, 2005," based on the results of a Statistics Canada survey. In 2005, there were at least 83 business incubators in operation in Canada that generated over $\$ 45$ million in funding. These incubators served over 900 clients that generated revenues of over $\$ 93$ million and supported over 13,000 part-time and full-time jobs. The national association for business incubators, the Canadian Association of Business Incubators (CABI), which has been in operation for over 18 years to promote the goals of its members.

With improvements in technology, business incubators have been evolving to better meet the needs of clients. Of the 83 business incubators operating in 2005, 77 were in full operation and serving clients. The remaining six incubators were still in the "start-up" phase, with a 2006 expected start date. 
Of the 77 fully operating business incubators in 2005, 71\% provided physical space to their clients. The remaining 29\%, or 22 establishments only provided "virtual" incubation services. As previously discussed, there is general agreement that the primary objective of incubators is to facilitate the creation of jobs for the local economy. According to the survey, however, the objectives of industrial growth and commercialization of technologies were also very important.

Figure 4 shows the breakdown of types of incubators in Canada in 2005. The majority 73 (88\%) provided primarily business incubation services, while ten $(12 \%)$ provided primarily technology services. At the time of the survey, six (7.2\%) incubators were at a start-up stage and had no clients. It is important to note that $44(53 \%)$ provided both services in some capacity (Statistics Canada, 2005, 8).

Figure 4: Type of incubator in Canada 2005

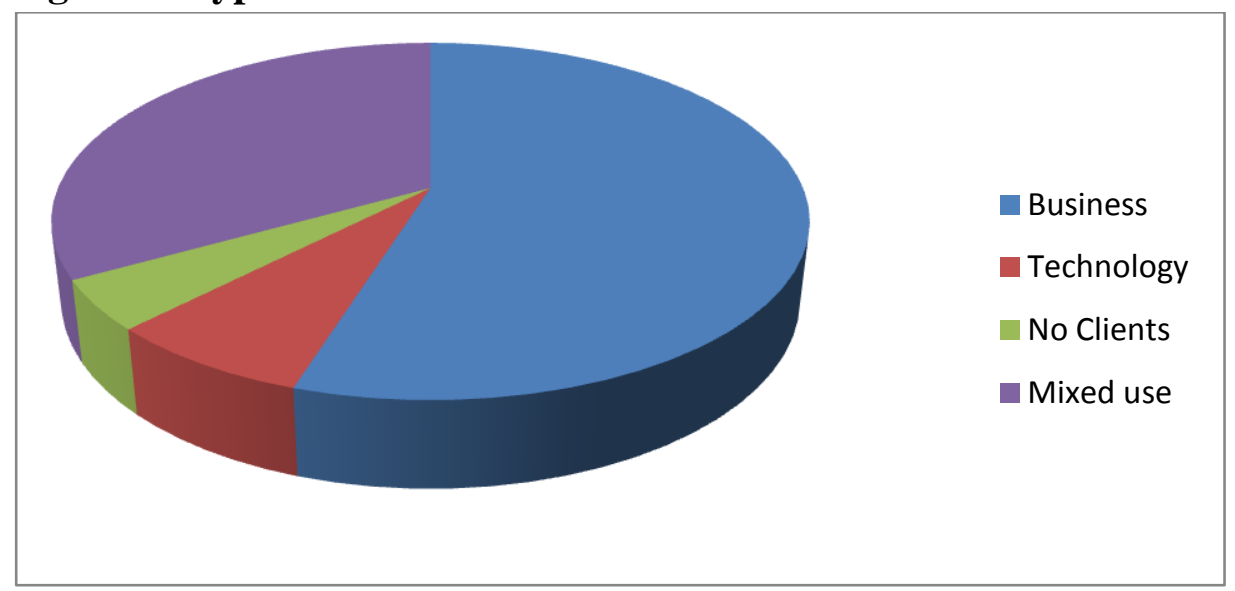

Source: Stats Canada, Characteristics of Business Incubation in Canada, 2005.

As shown in Figure 5, in 2005, incubators were fairly evenly distributed across Canada with the exception of Ontario where 24 incubators were located. The distribution for the other provinces/regions was as follows: Atlantic -15; Quebec - 15; Prairies - 15; B.C and Territories 14.

The operating model under which business incubators are structured also varies. Over half of business incubators (54\%) are structured as incorporated not-for-profit entities. Of this group, 12 or $27 \%$ are CFDCs. Table 4 summarizes the various types of operating models utilized by business incubators in Canada.

It would appear that co-location of incubators contributes to the success of the incubator and incubated businesses. The 2005 working paper by Statistics Canada proposes that co-location on the same premises plays a very important role in successful incubation. Location within the same four walls allows for greater mentorship, collaboration, and other discussions throughout the day. 
It also contributes to fostering the mentoring of start-ups. The building of such relationships is crucial to the success of the incubation start-ups.

Figure 5: Location of incubators across Canada

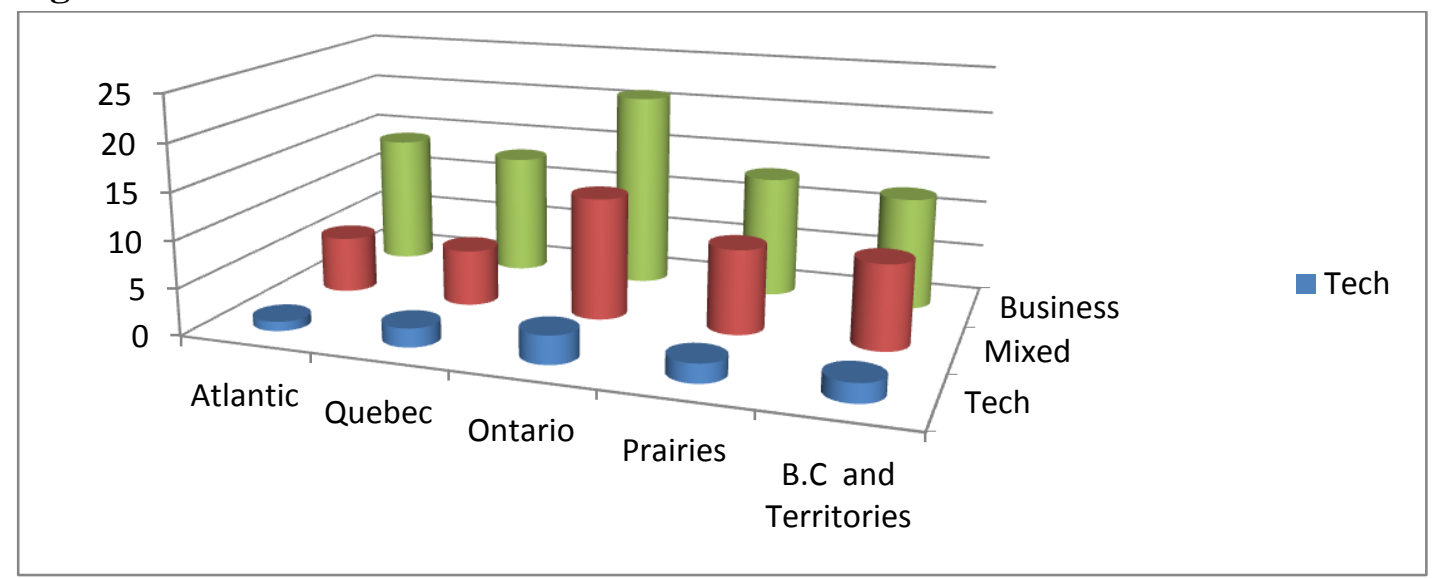

Source: Stats Canada, Characteristics of Business Incubation in Canada, 2005.

Table 4: Operational types

\begin{tabular}{|l|l|l|}
\hline Operating Model & Number of Incubators & Percentage of Total \\
\hline Incorporated Not-for-Profit & 45 & $54 \%$ \\
\hline Government Department or Agency & 13 & $16 \%$ \\
\hline University or College Assoc. & 10 & $12 \%$ \\
\hline Other & 7 & $8.4 \%$ \\
\hline Private for Profit & 6 & $7.2 \%$ \\
\hline Part of a Larger Private for Profit & 2 & $2.4 \%$ \\
\hline
\end{tabular}

Source: Stats Canada, Characteristics of Business Incubation in Canada, 2005.

The survey that was conducted with CABI members indicated that although the majority of incubators were co-located, $48 \%$ were not. The survey further suggested that the most popular co-location model was associated with a college or university $(26.5 \%)$. All those surveyed by the $\mathrm{CABI} /$ Statistics Canada survey, along with a survey conducted for the purposes of this paper, indicated that government plays an extremely important role - accounting for over 59\% of key strategic partners.

The diversity and respective proportion of partnerships is outlined in Table 5 below. It is common for incubators to draw on the experience and expertise of a partner. The average incubator employs 3.2 people with $70 \%$ of staff or 2.2 people made up of professionals (managers, counsellors, mentors). 
Table 5: Strategic partner in incubators

\begin{tabular}{|l|l|}
\hline Federal Government & $28 \%$ \\
\hline Provincial Government & $17 \%$ \\
\hline Municipal Government & $13.6 \%$ \\
\hline University & $10.6 \%$ \\
\hline Private Not-for Profit & $7.7 \%$ \\
\hline Other & $6.5 \%$ \\
\hline Private for Profit & $5.3 \%$ \\
\hline College & $4.1 \%$ \\
\hline Regional Government & $3.0 \%$ \\
\hline Lending Institution & $3.0 \%$ \\
\hline No Partners & $1.2 \%$ \\
\hline
\end{tabular}

Source: Stats Canada, Characteristics of Business Incubation in Canada, 2005.

\section{Floor Space}

In 2005, the average Canadian incubator occupied just over 11,784 square feet. This figure grew to nearly 18,000 square feet in 2007 - an increase of 51\%. During the same period, the average floor space occupied by incubator tenants grew from 6,667 square feet in 2005 to 15,571 square feet in 2007 (a 133\% increase). Given the modest increase in the quantity of incubators from 83 in 2005 to 97 in 2007, the growth in floor space utilized suggests that most incubators are dedicating increasing amounts of physical space to tenants. Figure 6 illustrates the significant change in the proportion of available floor space utilized by incubator clients.

Figure 6: Average floor space

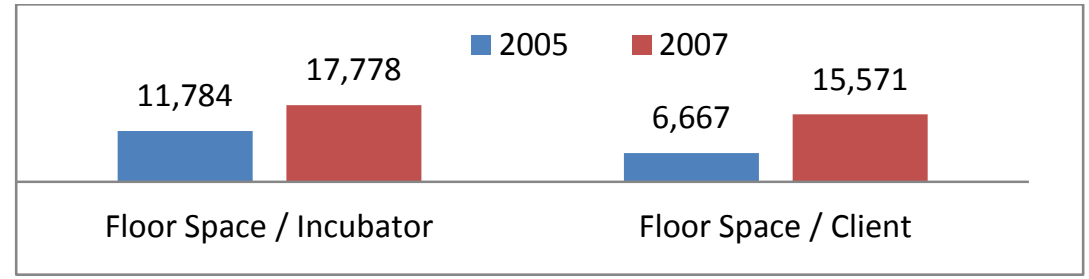

Source: Characteristics of Business Incubation in Canada, 2005.

The federal government in Canada was the largest funder of incubators, contributing just over $\$ 10$ million dollars or $22.6 \%$ of the $\$ 45$ million raised in 2005 . Rents and other services from clients make up approximately one quarter of the funding required (Statistics Canada, 2005, 11).

Table 6 presents some of the preliminary data released by Statistics Canada from the 2007 survey of business incubation and compares it with the 2005 data. 


\section{Incubator Objectives}

The next section is by far the most critical and is based on discussions with incubator managers and board members. The information gathered alluded to the importance of policies and the ability to enforce and abide by policies to ensure long-term sustainability.

The reasons and motivation for the creation of the incubators varied from organization to organization. The common thoughts were that incubators were created as a tool of community and economic development, and to support a transition or transfer of technology to commercialization, as well as to enable entrepreneurship. The generation of revenue for the organization was not mentioned or was noted just in passing. When the surveyed participants were asked to state their top three goals and objectives, on top of the list was the creation of jobs, followed by the growth of the industry and the diversification of the local economy. As mentioned above, the key to the success of a business incubator was the criteria for admission and exit or graduation. If there is demand for the space and there is no political interference, the criteria are likely to be met.

Table 6: Comparison of 2005 and 2007 statistics

\begin{tabular}{|l|l|l|}
\hline Space-Square feet & $\mathbf{2 0 0 5}$ & $\mathbf{2 0 0 7}$ \\
\hline Total Floor Space & 11,784 & 17,778 \\
\hline Occupied by Clients & 6,667 & 15,571 \\
\hline Funding-in millions & & \\
\hline Total & $\$ 45.0$ & $\$ 66.9$ \\
\hline Federal & $\$ 10.2$ & $\$ 17.4$ \\
\hline Provincial & $\$ 5.6$ & $\$ 17.1$ \\
\hline Rent and Fees & $\$ 10.8$ & $\$ 17.1$ \\
\hline Other & $\$ 18.9$ & $\$ 15.3$ \\
\hline Clients & & \\
\hline Avg \# of Clients/Incubator & 9 & 14.2 \\
\hline Receiving Services & $68 \%$ & $75 \%$ \\
\hline$\#$ of Employees/Firms & 65 & 31 \\
\hline Common Services & & \\
\hline Basic Business & $71 \%$ & $68 \%$ \\
\hline High Speed Internet & $64 \%$ & $70 \%$ \\
\hline Networking Activities & $56 \%$ & $71 \%$ \\
\hline Barriers to Incubators & & \\
\hline Funding & $63 \%$ & $49 \%$ \\
\hline Clients with no Funding & $65 \%$ & $49 \%$ \\
\hline Finding Clients & $65 \%$ & $38 \%$ \\
\hline Source: Stats Canada results $p 461 \% a t i o n$ & $88 f 06 x$ \\
\hline
\end{tabular}

Source: Stats Canada, results publication 88f006xie (page 11) 
Since available space in incubators is scarce, General Managers must, by necessity, employ a screening methodology of some sort to select tenants - if only just to clear the intake tray in as judicious a manner as possible. But, what if there was little demand for space? Would there be any need for selection criteria? Would first come, first served be the order of the day?

One approach to answering this question would be to examine whether prudent selection of tenants helps to make the incubator successful, or whether the incubator helps to make prudently selected tenants successful.

One could argue that if you only select entrepreneurs with excellent business plans and a top notch management team as tenants, then adding below market rents, a collaborative captive community of peers and readily available advisory services only serves to accelerate the inevitable success of the cream of the crop. On the other hand, one could argue that employing a "quasi-affirmative action" approach to selecting tenants might be a more appropriate approach for communities such as Elgin County, where the quality of the pool of candidates might not appear to be as stellar as in larger centres, but the magic of the incubator model could nevertheless be strategically employed to enhance the overall success rate of businesses. It seems intuitive that the selection criteria should vary from community to community, based on the objectives of the incubation program and the profile of potential tenants.

It only seems to make good sense to make incubators more accessible to entrepreneurs. What good is it to have an $87 \%$ success rate inside the walls, and a $33 \%$ success rate outside the walls? The admission and graduation criteria are examined below.

\section{Admission Criteria}

Current criteria of admission into incubators are set out in Table 7.

\section{Graduation Criteria}

In the Statistics Canada 2005 survey, the primary graduation criterion was a pre-determined period of time that was agreed upon at the entry level. This was followed by the facility no longer being suitable, and whether the business met or failed to meet the predetermined milestones (Table 8).

\section{Table 7: Current criteria of admission into incubators}

\begin{tabular}{|l|l|}
\hline Criteria & \# of time applicable \\
\hline Good Business Plan & 62 \\
\hline Sound Management Team & 46 \\
\hline Good Business Opportunity & 46 \\
\hline
\end{tabular}




\begin{tabular}{|l|l|}
\hline Commercialization Opportunity & 35 \\
\hline Availability of Financing & 32 \\
\hline Collaboration in Research & 29 \\
\hline Other & 26 \\
\hline Spin off from Stakeholder & 10 \\
\hline Working Prototype & 4 \\
\hline Foreign Applicant & 1 \\
\hline
\end{tabular}

Source: Stats Canada, Characteristics of Business Incubation in Canada, 2005, 88f006xie page 12.

\section{Table 8: Current criteria of graduation from incubators}

\begin{tabular}{|l|l|}
\hline Criteria & \# of incubators \\
\hline Predetermined Period & 53 \\
\hline Facility no Longer Suitable & 35 \\
\hline Reached or Failure to Reach Milestones & 34 \\
\hline Management Team & 30 \\
\hline Other & 24 \\
\hline
\end{tabular}

Source: Stats Canada, Characteristics of Business Incubation in Canada, 2005, 88fo06xie, page 12.

In 2005, business incubators served over 4500 clients. Almost $25 \%$ of these clients fell under arts and recreation, accommodation and food services, with another, almost $25 \%$, in the scientific and technical services group. The remaining 50\% was made up of: retail trade, transportation and warehousing - $8.2 \%$; manufacturing - $6.4 \%$; health services and education $-5.2 \%$; agriculture, fishing and hunting $-4.6 \%$. The remaining categories were mining, administration and support, cultural, public administration, real estate, insurance, and management.

Based on rate of utilization, for all sectors, the top six categories of services provided to virtual and onsite clients were:

- business basics - $61 \%$

- marketing assistance - $47 \%$

- accounting - $39 \%$

- connections to angel or VC investors - $22 \%$

- office space - $22 \%$

- resource materials - $22 \%$ 


\section{Barriers to Success}

Incubator managers were surveyed regarding the barriers to the successful operation of incubators. The majority responded that finding appropriate clients $(65 \%)$, having clients with little or no seed financing (65\%), and sources for funding the incubator operation (63\%) were the most significant barriers (Statistics Canada, 2005). The Statistics Canada 2005 study concluded by stating that the growth of incubators was on the rise. The demand for incubation service exceeds the supply, and one in three applicants are approved for client status.

\section{The case for the establishment of a formal business incubator - Elgin CFDC}

\section{Local economic impact}

In all the documentation reviewed, it is evident that the impact of incubators on the economy is sound and positive. In 2005, incubators in Canada were responsible for the creation of 12,874 full-time and 292 part-time jobs. Incubators also play a role as catalysts in encouraging entrepreneurial activity. People are more likely to consider participating in an activity when it is accessible and inviting, and when it offers a framework for education, training and support. Most people don't seek out entrepreneurship - it presents itself as an opportunity at certain times in one's life or career. Everyone that decides to become an entrepreneur wants to be successful. When an individual wants to succeed, that person generally commits to investing time and resources in the pursuit of that success. This usually entails research, buying books and magazines, photocopying articles at the library, attending seminars and meetings (often at restaurants and coffee shops), purchasing supplies (business cards, stationery, and a new computer), and installing a fax line, etc. These are all activities and expenditures that stimulate the local economy, and these preliminary steps are usually all it takes to change someone from a "nontrepreneur" to an entrepreneur - at least in their own minds. This is the point at which access to incubator services - virtual at first - would start to have a positive impact on the eventual outcome of their entrepreneurial initiative.

\section{General Observations}

What becomes of the $2 / 3$ of incubator applicants who are rejected as tenants? Do they give it a shot anyways and crash and burn on the boulevard of broken entrepreneurial dreams? Or, do they succeed against all odds?

Have opportunities been missed to provide a valuable "incubator lite" or pre-incubation service to self-identified entrepreneurial types; perhaps boot camps to prepare them for their next stab at entry into the entrepreneur's Shangri-La? 
What role can CFDC's play? Would it not be logical for example, for Elgin CFDC to also provide traditional or virtual incubation services, with a mandate to be a little less exclusive and in the process accepting more businesses with the objective of grooming them to reach the next level of development; perhaps feeding them up stream to "pure incubators"? What good is it to try and create the next Microsoft, and yet neglect a focus on creating clients for the next Microsoft?

\section{Conclusion and summary}

It is clear that business incubators are effective and can be self-sustaining operations by adhering to the best practices of the industry. Incubators could do more to affect the overall business success rate by relaxing some of the entry qualifications. Perhaps the internal success rate might suffer, but as long as it exceeded $33 \%$ that would represent an improvement over the results in a non-incubated environment.

Elgin County could benefit substantially from an incubator located or co-located with the Elgin CFDC. Many jobs have been lost that cannot and will not come back. It is absolutely the right time to take proactive steps and support a proven employment generator and local economy booster. Business incubators on average create over 150 jobs and generate revenues of $\$ 1.2$ million. Their economic impact is significant. Should a business incubator be located in Elgin County, the region will benefit from a much-needed permanent economic stimulus initiative.

As a final note, the insights gained from over 60 one-on-one conversations and interviews with incubator managers, administrators and other experts were incorporated in the content of this paper. A summary of the feedback is provided in the Appendix that follows.

\section{Author Biography}

John Regan was born in Calgary and raised in London. He is the General Manager of the Elgin Community Futures Development Corporation (CFDC), which operates under the name of Elgin Business Resource Centre (EBRC), in St. Thomas, Ontario.

John balances his role at the Elgin CFDC with being a council member for the Municipality of Thames Centre. In both roles, John helps grow and develop businesses. Before joining the Elgin CFDC, John's previous work experience spanned more than 25 years in a variety of business sectors and focused on business development, as well as sales and marketing processes. John has been self employed for most of his life and was an owner-operator in several businesses, including digital imaging, supply chain logistics, inventory optimization, die casting, automotive parts and accessories, and environmental products. In all capacities, John has been responsible for sales, marketing and customer support activities at a senior management level. Throughout his career, John has launched several new products and several new initiatives. Some of John's 
recent coups include the rebranding of the Elgin CFDC to the Elgin Business Resource Centre, as well as participation in opening of the Elgin/St. Thomas Small Business Enterprise Centre, and is working on bringing a small business incubator to the County of Elgin.

John started taking his EDAC courses at the University of Waterloo in 2006 and has completed all three years to receive his Ec.D. (F) certification in 2010.

In his spare time, John enjoys target shooting, boating, fishing, and cottaging with his family.

\section{References}

(A. Kenny, personal communication, Elgin Business Resources Centre, 2009).

Centre for Strategy and Evaluation Services (2002). Benchmarking of Business Incubators. Brussels: European Commission Enterprise.

Erlewine, Meredith. (2007). Comparing stats on firm survival. Measuring your Business Incubators Impact.

Fanshawe College. (2009). St. Thomas Campus and Employment Services Elgin, Current Unemployment Estimates 2009.

Hamdani, Bordt \& Joseph. (2008). The business of nurturing. Statistics Canada (Catalogue no.2 880006x).

Hamdani, Bordt \& Joseph. (2005). The characteristics of business incubation in Canada. Statistics Canada. ( Catalogue no. 7 88f0006xie).

Knopp, Linda. (2007). State of the business incubation industry, Athens, Ohio: National Business Incubation Association.

National Business Incubators Association. (2006). State of the business incubation industry.

Service Canada. (2009). London Labour Market Monitor, Labour Market Information Analyst.

Statistics Canada. (2009). London Labour Market Monitor: Services Canada. Access from http://www40.statcan.gc.ca/101/cst01/labor03b-eng.htm

Statistics Canada. (2007). Survey of business incubation. Science, Innovation and Electronic Information Division.

Stone, Mary. (2008). Mancuso, inventor of business incubator, dies. Rochester Business Journal. 
United National Industrial Development Organization. (n.d). Mapping UNIDO assistance. Accessed from

http://www.unido.org/fileadmin/media/images/resized/Investment_and_Technology/PLATECH/ Bahrain.pdf

University of Michigan. (1997). Business incubation works, Athens Ohio: National Business Incubation Association. 


\section{APPENDIX - CABI 2009 CONFERENCE PARTICIPANT SURVEY}

\section{Focused Survey Results}

The following is a summary of the information obtained from a survey conducted for the purpose of this research paper

1. What role(s) can/should government play in the development and implementation and management of business incubators?

Seventy-five percent felt funding should be a part of governmental role. Other comments collected were that government should look at business incubators as an effective tool in strengthening the commercial base in rural Canada. With their funding support, each rural incubator can help provide small business owners with the aftercare that will help guide them through the first and possibly second year of operating their business. There is always the issue of accountability and the funding agency should be provided with quarterly reports on successes, failures, number of people being employed and graduates. Government should also provide some key infrastructure that would otherwise be unavailable in the private sector; facilitate the one-stop-shop concept in an incubator by linking the various organizations and service delivery agents who assist business growth.

Clearly this is one economical vehicle that works. According to Statistics Canada companies that are incubated are $87 \%$ successful, after 5 years in business compared to a $25 \%$ rate for those that are not incubated. The government could provide funding in the set up of incubation programs with a finite timeline associated with this funding to ensure the business incubator is self sufficient. It is my expert opinion states a respondent ( Marie Lusser) that 5 years is long enough to support a business incubator as the funding is higher the first year and should decrease to nothing by the end of the 5th year. A business incubator is a business in itself and should be self sufficient within 3 to 5 years of opening its doors.

2. What role(s) can/should industry play in the development, implementation and management of business incubators?

Mentorship came back at $100 \%$. Industry should be available as mentors and possibly financial support to maintain and grow incubators in their region. Their established experience should be shared with the tenants of the incubator either in the form of a round table discussion once a month or quarterly. Established members of the business community should look at volunteering their time to help fledgling business owners over the rough spots. It was also thought that industry had a role of sitting on the board with $37.5 \%$ suggesting the board has a close relationship with industry as board members.

Industry can provided spin offs to the business incubator, it can become one of the 3Ps (private, public partnership) it can provide access to expert staff in the areas of economic 
development, business plan writing, marketing, intellectual property, know how, technologies and funding to name but a few. If industry is a partner it will have an active role in the business indicator which should be determined up front.

3. What role(s) can/should former incubated companies/entrepreneurs play in the development, implementation and management of business incubators?

When it came to former incubated tenants, it is vital that the incubated company be committed to the process and become actively involved in the weekly, bi-weekly or monthly training sessions and share their successes and failures with their counterparts and bring new ideas to the table if they see something that may help all of the other incubated companies in the cluster improve their operation. Seventy-five percent felt that all should become mentors and or provide training. Twelve percent of those surveyed felt the previous tenant should remain as an anchor tenant. They could also sit on the business incubator Board of Directors, become mentors to new start-up companies, experts on-call or in- house and champions of the business incubation program.

4. Can some/all incubation services be delivered effectively in a virtual environment, or is it necessary for the incubated company to occupy physical space in the incubator?

Eighty-eight percent were not very receptive to a virtual environment. It may work very well with the younger crowd, however the majority felt that hands-on, one on one meetings work better; this may not be the case in the new and improved world of communication.

5. Does incubation benefit certain types of businesses more than others? For example, are technology-oriented businesses more likely to thrive and develop in an incubated environment?

Over seventy-five percent felt that incubators serve high-tech, high growth companies. Although there is widespread and growing support for tech-oriented companies and the highpaying jobs that they can bring to a community, those surveyed felt that a tech-oriented incubator located in a predominantly low-tech community could not be viable unless it was open to all types of businesses. It was also felt that incubation can benefit all types of business categories. More financial support is available to tech and bio-science incubators, but financing can be available for any incubator if the vision supports the need for either an industry sector-based or geographically focused approach.

Business success occurs from interaction/networking with other businesses; it is helpful if they are like minded, but every business can learn from an accountant, a salesperson, etc.

6. What is the success rate of business incubators? 
Of those who responded all agreed that the incubation process was critical to the success of businesses. All agreed that the success rate of incubation was in excess of eighty percent.

7. Have they (business incubators) been shown to reduce the failure rate of new businesses?

Most felt that business incubators provide a full service to SMEs in building not only the business but also the management team and technologies. The network provided and nurtured by the business incubator is invaluable to growing strong Canadian companies as is a good management team.

eventy-five percent of those surveyed felt that there was a significant reduction in failure for incubated businesses. Twelve percent felt incubators had no affect on failure rates and twelve percent did not comment.

8. What can be done to improve the success rate of incubators?

Besides the response of "everyone is trying to find that answer", the responses focused around the following major items: more involvement from the established business community; the local politicians and by the general public; intake protocol; mentoring; networking; funding; accountability of incubators management.

The responses also pointed to the need to provide education on best practices, sharing methodologies, attracting champions at all levels, ensuring that the incubation management's toolkit is filled with the right mix of tools and strong national linkages with such organizations as CABI.

9. What is the relationship between an entrepreneur's academic or professional experience/achievement and the success rate of incubated businesses?

If the entrepreneur does not have the drive that makes a true entrepreneur, they are doomed to failure despite any educational achievements. Education is not always the determining factor when it comes to being successful in business. Some of our leading entrepreneurs in Canada and the US lack a degree.

If you were to survey business incubator managers, they would come from varied backgrounds, have different skill sets and may or may not have started their own business. This is also true of entrepreneurs and their experiences, education and background. There is no one definite answer as all entrepreneurs are unique and bring their own recipe for success. An entrepreneur's drive and commitment to building a successful business is most critical as is his or her ability to listen and accept direction and assistance from service providers and 
business incubator staff. The passion an entrepreneur brings to developing his/her idea and company will serve him/her well as long as he/she has a plan and follows it. Education is not what contributes to a successful business but rather the entrepreneurial spirit

10. Difficulty in accessing growth capital is a significant barrier to growing one's business. Should incubator program enrollees be given some guarantee of access to equity capital based on their performance in the program?

One hundred percent of those survey responded with no. There is no guarantee that they will be successful. Even if their performance is outstanding, it is up to the angel investor or venture capitalist to make that decision. There is no free lunch.

The role of the incubator is to coach, direct and assist the company in its growth. Funding ibis only one aspect of growing a successful company. If the management team is weak, if the business plan is weak or is not adjusting with the growth of the business, if the idea is not strong etc. no matter how much money is given to a business it will eventually fail. Funding is just one aspect of growing a business.

11. What is the most common reason(s) for the failure of an Incubator?

Lack of funding, lack of sustainability, the wrong management team, no understanding of what it takes to grow a successful business, lack of direction, no critical mass, lack of a business plan, lack of direction, no champion. The responding participants also identified not following the entrance and exit criteria as a reason for failure.

12. What would you consider to be the top "best practices" and critical success factors that contribute to the success of an incubator?

The responses included: run the incubator as a business with milestones, a sound marketing plan and engagement from the local community; practice what you preach to your clients; be consistent in the delivery of all programs; have the right management team in place; have an active and committed Board of Directors that are there to support the incubator in its growth with no hidden agendas; strong entrance and exit criteria. good matrixes and statistics to demonstrate to stakeholders program successes; strong community partners and champions; a flexible building that adjusts to client requirements and adapts to meet your clients needs; ongoing education of staff to ensure they have the best skill sets to meet the client's needs; review your business plan on a regular basis; and conduct exit interviews with your clients to see what you could do to better by learning from them what did and did not work. 
Also noted was making it compulsory that the tenants commit to a once a week training/bull session. The tenant must be open to criticism from his/her peers and must be willing to accept a mentor if available. The tenant should attend any sessions where speakers are brought in to talk on specific business related topics. The rent has to reasonable but it cannot be too low that it results in the centre going into the red. Any advertisements should be shared by the tenants. The tenant must be willing to a pro-rata agreement on shared equipment and reception costs. The tenant must be willing to cooperate in open house projects. The tenant must get along with all of the other tenants. The tenant has to respect the incubator manager and the role in the incubator. The incubator manager must be flexible and able to multi-task. The incubator manager must be a strong communicator and arbitrator. 